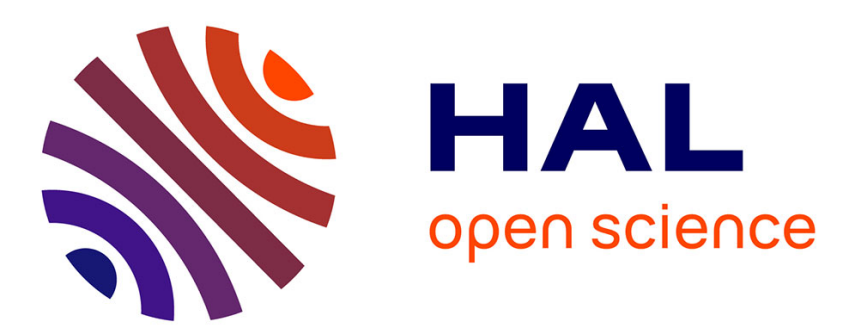

\title{
The power of (the) union. Trade-unionism and workplace democracy in a French recovered factory \\ Maxime Quijoux
}

\section{To cite this version:}

Maxime Quijoux. The power of (the) union. Trade-unionism and workplace democracy in a French recovered factory. Review of Social Economy, 2020, vol. 78 ( $\mathrm{n}^{\circ} 3$ ), pp. 431-449. 10.1080/00346764.2020.1775875 . halshs-03097753

\section{HAL Id: halshs-03097753 \\ https://shs.hal.science/halshs-03097753}

Submitted on 5 Jan 2021

HAL is a multi-disciplinary open access archive for the deposit and dissemination of scientific research documents, whether they are published or not. The documents may come from teaching and research institutions in France or abroad, or from public or private research centers.
L'archive ouverte pluridisciplinaire HAL, est destinée au dépôt et à la diffusion de documents scientifiques de niveau recherche, publiés ou non, émanant des établissements d'enseignement et de recherche français ou étrangers, des laboratoires publics ou privés. 


\section{The power of (the) union. Trade-unionism and workplace democracy in a French recovered factory}

Maxime Quijoux, research fellow at the CNRS, member of the LISE-CNAM

maxime.quijoux@lecnam.net

LISE-CNAM,

1LAB40,

2 rue Conté,

75003 Paris, France.

Abstract: Since the 2000s, workplace democracy has become the vehicle of a new political imagination that may offer an alternative to the excesses of capitalist globalization. However historical and sociological research has regularly highlighted difficulties of establishing democratic structures in the workplace. What happens when a trade-union becomes the main actor of this democratization? Underlining the strong bureaucratization of the trade union field, studies on trade unionism seem to predict low potentials. The case of a cooperative takeover of a French company by the CGT union in the early 2010s gives us the opportunity to verify this claim empirically. The examination of the transformation of this printing company into a worker cooperative leads to two main results: firstly, we will see that while trade union bureaucratization allows the takeover of the company - thanks to trained and professionalized organizers - it also constitutes an obstacle when setting up the main cooperative schemes, as shown by the lack of participation in general meetings. In a second phase, however, it will be seen that trade unionism produces its own participatory mechanisms: by placing members from each sector on the board of directors - from the reception to the printing presses and the sales department - the union sets up a "sociological democratization" which has important effects on the functioning of the enterprise: the cooperative thus creates a continuum of interactions and the possibility to contest which constitute "worker control" over the new management.

Keywords: trade unionism, cooperative, worker, takeover, participation, work.

Since the 2000s, workplace democracy has become the vehicle of a new political imagination that may offer an alternative to the excesses of capitalist globalization. Analysts studying social movements, to which they are often close, have sought to explain the various ruptures that certain experiences of self-management at work have brought about. The proliferation of worker-recovered companies following the 2001 crisis in Argentina has provided a significant source of reflection on the contours of self-management. Despite what are often precarious employment and working conditions (Quijoux, 2012), these experiences are frequently presented as examples of a better division of labour and involvement in the definition of work (Rebon, 2004). They are also characterized by the priority given to employment over profits and even over wage levels (Ruggeri, 2010; Rebon, 2004; Fernandez Alvarez, 2016). These cases have since become the source of new political (e.g. Wright, 2010; Holloway, 2010; Azzelini, 2018) as well as academic (e.g. Ozarow \& Croucher, 2014) ambitions. 
However, the enthusiasm that the (re)discovery of democratic models of work has generated should not obscure a certain scepticism in the literature. While some analysts, particularly in political theory, point to the need to reduce the gap between citizenship in the public sphere and the sphere of work (e.g. Pateman, 1970), research on experiences of workplace democracy regularly focuses on the causes of their collapse. In an article published in 2016, Plys examines the reasons for the failures of worker self-management attempts in the 1950s, 1960s and 1970s in the Third World. Originating in revolutions, reforms, or social movements, these initiatives failed not so much for economic reasons as for the threat they posed to political regimes (Plys, 2016). In this historical sequence, self-managed companies usually ended up being nationalized. Research on the long experience of Yugoslav selfmanagement has, for its part, often been critical of a system that was reluctant to represent workers (Broekmeyer \& Marius, 1977) despite the spaces for information and exchange that it provided (Taylor et al., 1987). Based on cooperative experiments conducted in the PacificNorthwest plywood industry, Greenberg (1981) dampened any hopes that these experiments might be a wellspring of new socialist-leaning practices in capitalist countries, and described the members of cooperatives as driven by 'petty-bourgeois' considerations. My earlier research has shown that in the case of worker-recovered companies in Argentina, the employees who founded cooperatives were those who fostered close ties with their former boss, explaining the reproduction of competitive and social control practices (Quijoux, 2011). More recently, a comparative study of two large Spanish and English cooperatives shows that the status of cooperative members is highly ambivalent. Owning one's company does little to encourage forms of collective commitment and responsibility (Basterretxea \& Storey, 2018). ${ }^{1}$

What happens, then, when the main union takes over a company as a cooperative? Despite the one-time rapprochements during the $20^{\text {th }}$ century, trade-unions are actually far from the paradigm of cooperativism. Both in France and in the United Kingdom, unions have a historic mistrust of companies which "transformed employees into bosses » (Lojkine, 1996) or divided workers' interests (Tuckman \& Knudsen, 2016). In France, moreover, the weakness of the cooperative movement (63.000 employees) makes it appear as a very marginal issue (both main unions, the CGT and CFDT, count ten times more members on average each), while in United Kingdom worker cooperative were accused of contributing to the privatization of the public sector (Pendleton \& Robinson, 2017).

More prosaically, trade unionism seems far removed from cooperative values by the very nature of its operation. Since the 1970s, research in industrial relations has shed light on the phenomena of bureaucratization that structures union life. In the footsteps of Richard Hyman (1975), many investigations had shown that organizations that defend workers' interests were characterized by power being organized around a small number of full-time officers, paid and professionalized staff, who were in charge of the negotiation in the name of all members of the trade-union. This asymmetry in decision-making has gradually spread to the lower strata of organizations, with unionism invariably being a source of power held by the few (Hyman, 1979; Heery, Kelly, 1994). More recently, however, Darlington et Upchurch (2011) have recalled that this process is not linear: if a dominant social position can lead a trade-unionist to defend the current system, it can also, according to historical contingencies and local

\footnotetext{
${ }^{1}$ In addition, see the survey of recent philosophical debates on the question by Frega, Herzog and Neuhäuser
} (2019). 
configurations, lead him or her to defending demands coming from the bottom. After a "participatory impetus" during the 1970s, in a context of industry decline, trade-unions have experienced, from the 1980s onwards, a bureaucratic revival characterised by a strong cooptation of trade union leaders by employers (Kelly, 2004; Darlington, Upchurch, op.cit.).

French investigations have found out similar outcomes : Andolfatto and Labbé (2011) have emphasized the way in which the interests of trade union organisations have gradually become autonomous from those of the workers they are supposed to represent: between financial dependence on the state and growing involvement of elected trade union officials in various quasi-governmental institutions (labour courts, unemployment, pension and training funds), trade unionism faces a substantial distance from the workers. According to these authors, this explains why France has the lowest rate of trade union membership in Europe. Others have qualified these outcomes, pointing to the diversity of union profiles (Giraud \& al. 2018) and the pressures on grassroots activist work (Mischi, 2016). Nevertheless, just as in the United Kingdom, the bureaucratization of trade unions, that is, the process of differentiating and opposing practices and interests according to one's position in the organization, is a key point for understanding French trade union action. Therefore, to what extent can trade unionism contribute to democracy at work? In what ways do trade union positions and practices, particularly bureaucratic ones, shape it? Are trade unionists, in turn, doomed to failure?

The employee takeover of the Helio Corbeil printing works provides an illuminating example of the effects of trade unionism on democracy at work. On 7 February 2012, the employees of the Helio Corbeil printing plant in Corbeil-Essonnes, a town located about thirty kilometers south of Paris, won an unexpected victory: the commercial court accepted the takeover bid put forward by the factory's trade unionists to set up a Sociéte Coopérative et Participative (SCOP) or workers' cooperative. ${ }^{2}$ While this initiative succeeded after struggling for only 6 months, it was the result of a longer period of union mobilization. From the late 1990s until the cooperative was formed in 2012, the workers, led by their delegates from the General Confederation of Labour (Confédération Générale du Travail or CGT), ${ }^{3}$ mobilized a wide range of collective actions to limit job losses and prevent the company's closure. In the early 2000s the company still employed nearly 400 people; the recovery managed to save the last 80 jobs at the plant. As is often the case in this type of participatory enterprise, the motive for the worker takeover lay less in democratic aspirations than in willingness to protect employment (Gold, 2004; Fernández Álvarez, 2016; Gourgues, 2018; Reid,

\footnotetext{
2 A SCOP is a for-profit company whose employees own the majority of shares. As members of the cooperative enterprise, the employees elect the board of directors and CEO every four years. The company's profits are divided between the 'labour share' assigned to member employees (a minimum $25 \%$ of profits) and reserves intended for investment in the company. There are now 2,991 SCOPs in France with more than 53,000 employees - including 27,800 members - and a turnover of 4.6 billion euros. Almost one in two belongs to the service sector, one in three to construction and industry. Source: http://www.les-scop.coop/ 2017

3 Founded in 1895, the CGT was for a long time the biggest trade union in France. It currently claims to have more than 600,000 members (3\% of the paid workforce), but had a membership of nearly four million workers at the time of the Liberation. Following the Russian revolution, it appeared to be the extension of the French Communist Party (Communist Party membership was compulsory for all CGT leaders until the mid1990s). Since the early 2000s, it has claimed independence from all political parties. The CGT remains very present in the country's main industrial sectors (automotive, metallurgy, chemistry, agri-food), the civil service (transport, hospitals, administration) and the large formerly national companies (the post office, telecommunication, electricity). It is authorized to negotiate at company, industry and national levels.
} 
2018).Furthermore, the CGT, which was for a long time close to the French Communist Party (PCF), is one of the confederations most hostile to the cooperative movement (Lojkine, 1996).

This article is based on research conducted at this printing plant, located in the Ile-de-France region, using two main methods: archival research based on a set of trade union archives dating back to the 1980s (social balance sheets, chartered accountant's report, company agreements, works council minutes, trade union information, handwritten notes, press articles, company magazines, letters and emails); and a 22-week participant observation between October 2012 and April 2013, when I interned at the plant. I was responsible for improving communication between the new management and the member employees, and consequently attended all board meetings, governance training sessions and the company's general meetings. But most of my time was spent with the different groups in the plant in various settings and situations: with teams of workers attending to the press, at the works council office $^{4}$ with the trade unionists, in the management office and accompanying the new CEO on business outside the factory. This wide variety of observation points and interactions provided me with a comprehensive view of how the company operated, giving rise to a book-length analysis published in 2018. Since the end of the observation period, I have been in contact with the members of the SCOP whom I visit on an ad hoc basis (once a quarter on average).

Based on this case, I advance two sets of findings. First, study of the collective action that led to the takeover suggests a paradox. By making collective bargaining the core of its activist activity, as Hyman claims, bureaucratization leads to "professionalize" its union leaders, i.e. equipping them with a range of economic, legal and social skills (Heery, Kelly, 1994; Hyman, 1989; Quijoux, 2018; Thursfield, 2012). These skills appear indispensable when it comes to transforming their business into a cooperative. However, if it is professionalization that makes it possible to "democratize" the factory formally, it remains an obstacle when a cooperative regime is established: the concentration of skills in a small group of trade unionists leads to delegation and self-censorship on the part of the rest of the employees, which renders the main participatory mechanisms inoperative. The general meeting, the most common and emblematic practice of the cooperative system -because it is compulsory at least once a yearconstitute un relevant example.

In a second step, the aim is to qualify this first result and to highlight another effect of unionism on the cooperative enterprise. Unlike most cooperatives, whose management is composed exclusively of white-collar workers, the CGT decided to include representatives of all the occupations within its board of directors: from the reception to the printing presses and the sales department. This "sociological democratization" of the company's management had unexpected democratic effects when the cooperative was set up: it made it possible to get around the phenomenon of self-censorship by making possible a continuum of interactions between the basic workers and the members of the board of directors. This continuum of

\footnotetext{
Works councils were instituted following the Liberation and are still one of the main institutions representing employees in French companies. Works councils are mandatory in companies with more than 50 employees and are financed by the employer. They are in charge of managing a set of social measures - from the distribution of entertainment tickets to subsidised holiday accommodation - but above all they serve to counterbalance the employer's power through a set of legal and juridical means. The employer must consult the works council for a range of decisions relating to the organization of work, the economic situation and the company's finances. In case of doubt about the transparency of the accounts, the works council may request the intervention of an accountant at the expense of the employer.
} 
interaction was also encouraged by the isolation of the teams: nearly 100 employees worked in 3 shifts spread over 19,000 square meters. In particular, it also made possible protest actions in the workshops. More broadly speaking, we will see that the presence of blue-collar workers created the conditions for "workers control": the members of the board of directors are required to take the opinions of their workshop colleagues into account during board meetings, because they are subject to their comments on the decisions taken at the head of the cooperative in the workshops or offices.

In short, trade unionism carries its own forms of social domination and thus seems to have little respect for the cardinal values of the cooperative movement, like the election of the leadership, deliberation, and the general assembly. Nevertheless, it appears to be the creator of other democratic mechanisms such as sociological democratization of the leadership and various forms of control by the workers. Although less formal, these are no less effective.

\section{A recovery marked by union professionalization}

1. A factory with a strong union presence

Helio Corbeil is a two-hundred-year-old factory with many social characteristics of a 'workers' fortress', that symbolic seat of a united, conscious, and combative workforce. The factory specializes in rotogravure printing ${ }^{5}$ and produces about ten million copies of television magazines each week. Almost all the employees are skilled male workers. The collective agreement for the sector the company belongs to is fairly favourable for blue-collar workers the lowest wage is 1.800 euros net per month - which compensates for difficult working conditions (shift work, noise, exposure to hydrocarbons, etc.). Traditionally, employees often started working at Helio Corbeil at a young age - between 15 and 20 - to make a career there. As soon as they joined the company, they experienced rapid professional socialization through learning the trade on the job and socializing with co-workers. There was also the feeling of belonging to a large industrial group; employees who arrived in the 1980s and 1990s, often through an acquaintance and/or the printing school, joined a factory owned by the Hachette group, one of the world's leading publishing companies. Many see this period as a 'golden age' to which they like to identify and refer.

Helio Corbeil is also strongly marked by trade union activism, in particular by the CGT. In the period at stake, 1980-2013, there was a very high rate of CGT membership in the company. In 1996, for example, one third of the factory's workforce belonged to this union (150 out of 449 employees), which obtained 87.6 per cent of workers' votes in the workplace elections. The CGT was also the majority union among managers. Conflicts were frequent within the factory, with strikes made particularly effective by singular production conditions: with strict printing deadlines to meet - on pain of penalties - plant managers generally had little room for maneuver when employees stopped production. However, strikes were just one part of the union's protest activity, which was also characterized by a strong 'culture of intervention in the management' of the company (Lojkine, 1996, p. 5). Employee

5 This is an intaglio printing process based on the transfer of images engraved on copper cylinders. This technique makes it possible to produce high volumes of print. Gravure printing was made part of French intangible cultural heritage in 2008. 
representatives demonstrated a keen understanding of the technical and economic challenges facing their plant. They did not hesitate to challenge management's choices using documents that their mandate allowed them to obtain, information from the union - within other companies or the federation - or analyses produced by accounting firms. In this sense, the local branch of the CGT at Helio Corbeil was characterized by the existence of a union elite that relied on both the qualifications and the stability of its union representatives. In thirty years, there were only two works council secretaries and seven trade union delegates, with the same two members of the company's managerial staff dominating these positions until the end of the 1990s. While the new generation had less trade union experience and fewer qualifications than the previous generation, they benefitted from the theoretical and practical knowledge of their predecessors, consolidated by entire careers dedicated to trade unionism. Antoine, ${ }^{6}$ the future CEO, had a BTS, ${ }^{7}$ in addition to a career holding both management positions and union responsibilities.

When the company faced a series of restructurings in the 2000s, this trade unionism helped limit the effects. Although the workforce was reduced by 80 per cent in about ten years, the workers managed to avoid the company's liquidation. At each redundancy plan, employee representatives deployed a repertoire of collective action - stoppages, strikes, bringing in the labour inspectorate, etc. - combined with management demands, proposing their own plan to revive the plant. At the time, the employees of Helio Corbeil benefitted from particular local circumstances. The town's mayor was Serge Dassault, a powerful French industrialist. ${ }^{8}$ In 2004, Dassault acquired the press company that was Helio Corbeil's main customer. Concerned to ease an industrial dispute involving his city's iconic firm, Dassault has repeatedly assured trade unionists that its press company would guarantee the plant's orders. When Helio Corbeil went into receivership in early 2010, the collective of employees already had all the means to take over their company. They had people with managerial know-how and a large support network - one of the leaders belonged to the CGT's national executive. The local configuration gave them financial guarantees to support their bid; not only did the mayor's company undertake to provide the plant with orders, but Dassault granted an interestfree loan of several tens of thousands of euros to build the firm's capital. Added to the severance pay and half a month's bonus for the 80 employees who joined the SCOP, this sum was enough to convince the commercial court of the viability of their cooperative initiative. Nevertheless, the recovery remained a union victory, made possible by a high degree of professionalization among its officials.

2. Trade union professionalization as an obstacle to the adoption of cooperative practices

When in the 1970s the United Kingdom experienced an explosion of corporate occupations and the emergence of 'new-co-operatives', Richard Hyman did not hesitate to describe these experiences as 'qualitative as well as quantitative advances in struggle' (1975). However, he omitted the fact that these initiatives were largely the work of highly qualified sectors,

6 Antoine, aged 40 at the time of the study, became the new manager of the plant. He was formerly the CGT union delegate. We will come back to his story later.

7 The Brevet de Technicien Supérieur (BTS) is the equivalent of the BTEC Higher National Diploma.

8 The son of a well-known industrialist, Serge Dassault was a graduate of the prestigious Ecole polytechnique, CEO of a multinational company, senator of Essonne and as of 2016 had the fifth largest fortune in France with an estimated wealth of 20 billion euros (according to the Challenges.fr website consulted on 23 February 2017). 
particularly trade unionists from the engineering sector, who were therefore highly professionalized (Gold, 2004). In Hélio-Corbeil, this trade union professionalization could also be observed. It is based on a strong verticality in the conditions of collective action, which seems to run counter to the adoption of cooperative practices. The SCOP was prepared in a hurry - the takeover bid was drawn up in less than six months - and was not the product of a collective initiative; it was driven by CGT trade union representatives who drafted its statutes and lobbied public, financial and judicial institutions during the mobilization process. In fact, contrary to the 'one person, one vote' principle that generally characterizes this type of firm, ${ }^{9}$ no election was held to select the new management when the cooperative was established. The union leaders alone appointed the six members of the board, taking on half of the positions themselves, including that of the CEO. While this practice is legal when a SCOP is first formed, ${ }^{10}$ it highlights the significant division of labour within the union's activism. The employees were used to relying on this small group of union officials with strong technical, financial, legal and political skills and therefore did not object to the lack of elections. Rescuing the company had been enough to legitimize these unionists' leadership of the new cooperative in the workers' eyes.

During the cooperative's first year of existence, however, the workers' new-found status as co-op members soon raised their expectations, particularly regarding the distribution of profits, which was sometimes a source of dissatisfaction. Some members considered that the amount assigned to the labour share was too low and criticized management's choice to favor savings. ${ }^{11}$ This protest soon took the usual forms of the trade union repertoire. Led by Bernard, one of the few union leaders who did not join the board of directors, the dissatisfied members regularly raised their demands at works council meetings. But under the cooperative framework, the SCOP general assembly appeared as a new place to express their complaints. On the eve of the first general meeting, some planned to take advantage of this space to settle the score with the new management, such as François, an operator in his forties:

- How do you see the general meeting that's coming up?

- I hope it's going to be war.

- You're hoping for a war?

- Just to make it clear to him [Antoine] that we're not sheep. You can't just do what you want. If it comes to a clash, then so be it. [...] We're not children, you can't just explain things to us and that's that. That's why we formed the co-op! It's so we can feel good at work, so we can change direction.

Far from being an isolated feeling, many employees - including the CEO - expected the record to be set straight in no uncertain terms at the general meeting. According to my estimates, at least twenty members of the cooperative - a quarter of the total workforce regularly expressed their disapproval during the first year. Some considered exercising the right of initiative that would allow elections to the board of directors to be held. ${ }^{12}$ But against

\footnotetext{
It should be recalled that in cooperative enterprises, the management is regularly elected from among the members, regardless of the amount of their contribution to the company's capital.

10 When a cooperative is founded, the initiators may unilaterally appoint the persons in charge of the company. In this case, however, the initial term is limited to three years instead of six years for a regularly elected board.

11 It should be recalled that the law on cooperatives imposes a minimum distribution of surpluses of $25 \%$ towards the labour share, with the rest going to the firm's reserves.

${ }_{12}$ The right of initiative is one of the democratic mechanisms of the SCOP. With the support of a minimum of one-fifth of voting members, they may add an item to the agenda and with one-tenth, convene a
} 
all expectations, the confrontation did not take place. As the following excerpts from my observation notes show, no conflict arose when the discussion was opened up to the floor, and the leadership's decisions were endorsed:

[At the end of the meeting] Antoine invites his colleagues to take advantage of the auditor being there and ask questions about the accounts. Nicolas, Georges and a few others encourage Bernard to speak up: 'Bernard, go on!'. He raises his hand, provoking their satisfaction, even the amusement of some of the audience: 'Yes, it's just a small question'. He raises a technical accounting question that is quickly resolved by the auditor. Another worker then points out a typo in the accounts. Finally, Jean ${ }^{13}$ questions management about the company's savings [...] The time comes to vote. Antoine calls on his colleagues to vote on the accounts: 'Who is against? Who abstains?' No one is opposed. Bernard abstains, causing a few smiles both in the audience and on the platform. [...] Antoine then has his colleagues vote on two or three other points in the same way and with the same result. Once the vote has been taken, the auditor and the lawyer withdraw. Bernard also leaves. ${ }^{14}$

While supposedly the high point of the company's democratic calendar, the general meeting was not, in the end, the scene of any attempt to call the new managers to order. As we will see later on, only one grievance, concerning one particular point of work organization, was addressed on this occasion. The gap between the predicted revolt and the widespread passivity during the general meeting clearly demonstrates how little inclined the employees were to make use of the main participatory tool at their disposal. Faced with highly experienced trade union activists, the employees seemed incapable of putting forward their criticisms and positions. Even among managerial staff, the new management seemed to enjoy a legitimacy that forestalled any criticism of its decisions. As some remarks by the production manager (number two in the company's organization chart) show, the new management had a specifically political competence that set it apart from the rest of the employees:

[...] he [Antoine] has surprised me. I think he's managing pretty well. Good for him. I'm happy for him, and for us too. You see, some people came to me saying 'Why don't you take the [CEO's] job?' Well no, it's not something I'm into. No. I don't feel up to it. I don't have the gift of the gab. Going to meetings to yack for two hours, I don't know how to do that. I don't like it and I don't know how. I mean, for Antoine, that's every day. I can't see myself going to see Dassault, going to see the clients, and anyway, let's say politically and union-wise, it's a post that was meant for Antoine. [...]

Between the board of directors being appointed and the lack of opposition to management, everything seemed to point to the emergence of a new vertical power structure in the company. But did the lack of direct confrontation condemn the workers to silence afterwards? We will see in the next section that other forms of participation appeared: the spatial configuration of the company on the one hand and the new sociological composition of the management on the other hand helped give rise to a degree of 'workers' control'. This new form of participation nevertheless remained highly dependent on past trade union capacities and practices.

general meeting. They can also trigger a cooperative review, that is, a compliance audit, to ensure the firm is entitled to cooperative status and its tax benefits.

${ }_{13}$ Jean, aged 50 at the time of the study, is the 'machine operator' - it is his job to oversee the printing quality of the press.

Field notes, 17 April 2013. 


\section{Localized resistance and worker control: forms of participation permitted by the sociological democratization of the factory}

1. The workshop, a space for union counterstrike

While their financial contribution pushed some employees to claim a right to have their say, discontent rarely took the path of open dispute at Helio Corbeil. Yet the employees were not completely helpless in the face of the reconfiguration of power structures in their firm. While they failed to appropriate the designated arenas of deliberation or to voice their criticism of their new leader, they fell back on a much more familiar space: the workshop. The factory occupies 19,000 square metres on a 37,000-square metre plot of land. The work at Helio Corbeil is spread over four large, quite distinct areas. The administration and the electrotyping sector share the same building, but their work areas are separated by a large hall. In an adjacent warehouse, production combines the two main rotary presses and, in a related area, the maintenance sector (see Graph 1). In addition to the geographical distance, there are also different working hours; the administration only works during the day whereas the production department has teams of five workers organized in shifts, headed by a foreman. The teams have often been working together for several years. They know each other well and enjoy a high degree of autonomy in their work. Free from scrutiny, teams form tight-knit groups that allow workers to deploy critical capacities.
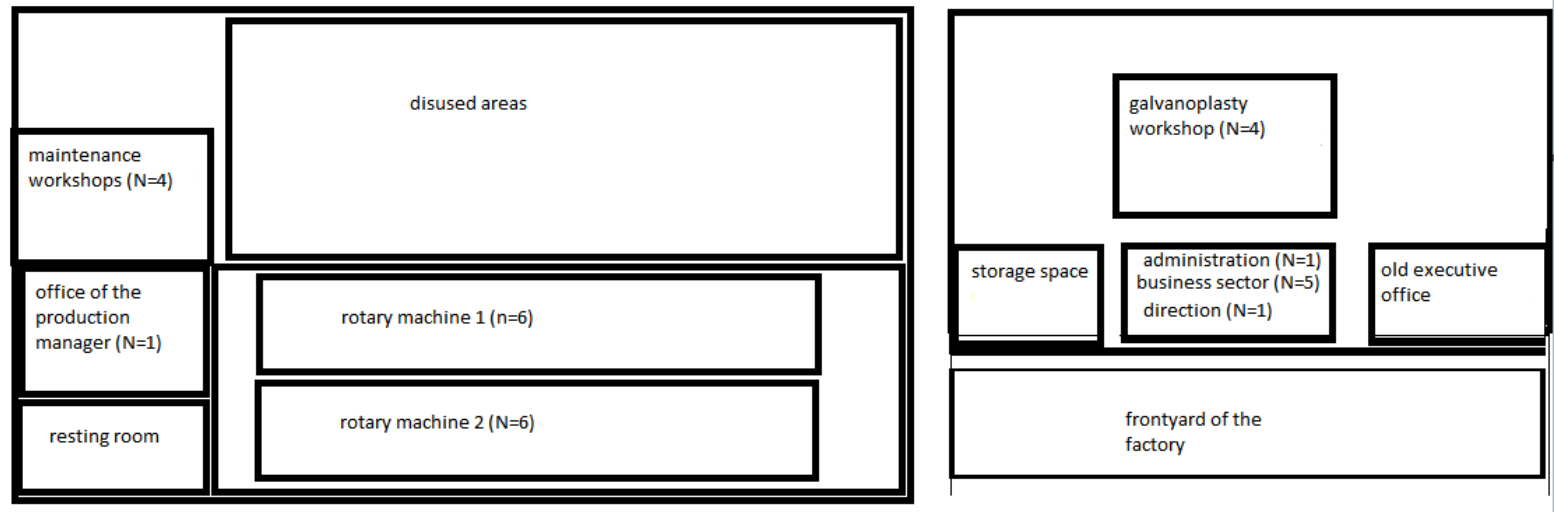

Sketch of the factory $\mathrm{N}=$ number of members team

One initiative clearly illustrates the possibilities for protest that the workshop's intimate nature affords. In April 2013, the management informed employees with a note on a notice board that it would temporarily modify the work schedule. An Italian company was being brought in to do some work to improve the capture of toluene - a solvent used to degrease the cylinders - and production would consequently be stopped for three Mondays and Tuesdays in May and June of that year. Management proposed to catch up those lost days on weekends, day and night. The investment, amounting to 200,000 euros, followed a formal notice from the prefect urging the company to recycle its pollutants better or risk a fine. But management pointed out that it would also improve working conditions by reducing the workers' exposure to the hydrocarbon solvent and, moreover, would make it possible to produce and sell larger quantities. Finally, the note stated that three-quarters of the Sunday day shift - 12 hours would be paid at an overtime rate of two times the regular hourly rate. The letter ended by 
stating that this 'proposal' would be submitted to the following works council meeting for 'approval'. 15

The next day, copies of an unsigned handwritten letter were put up in different parts of the factory, particularly on the presses and in the changing rooms. The letter protested against what its author or authors considered the 'unilateral' implementation of this adjusted work schedule. Mentioning respect for '[their] personal and family lives', the letter not only recalled the freedom to refuse this change in their schedule, but also demanded that all Sunday hours be paid in overtime, again in the name of 'the personal and family impact' (underlined in the original). This letter had the effect of encouraging some people to overcome their feeling of 'incompetence' in terms of public speaking. During the two hours of the general meeting, the only opposition that emerged followed on from the letter, as I recorded here:

\begin{abstract}
Antoine then invites them to respond to everything he's said. Once again, the audience is silent. Antoine insists: 'Well then, don't you have anything to say?' After a few minutes of hesitation, Olivier, the driver, calls out to him: 'I have something to say. I don't agree that we should be forced to work on Saturdays and Sundays instead of Mondays and Tuesdays. Frankly, I think we're already giving enough for the co-op. We were asked to make an effort; I think we've already done a lot. But this is too much, you have to respect our family lives.' Antoine reacts immediately: 'To start with, nothing has been imposed. On the contrary, we wanted to approach you as soon as possible to make sure you were informed. When we don't communicate, you're not happy, but when we do you aren't either!' Olivier, supported by others: 'No, no, no, it wasn't clear at all!' Antoine adds: 'In addition, I find that writing an anonymous letter and pasting it all over the factory when you could have come directly to see me, that's really pushing it.' [...] Pascal, Olivier's assistant on the rotary press, pipes up: 'To be honest, I wrote the letter. We wrote it because we couldn't see anyone to talk to.'
\end{abstract}

This excerpt shows the gap between the new management and the rest of the employees. By stating that they "couldn't see anyone to talk to", while the management is largely composed of CGT members, including the CEO and the steward, the author of the letter confirms the complexity for the grassroots employees to bring their demands directly to their representatives. In this sense, while one might have expected a rapprochement in the framework of a cooperative enterprise between trade unionists and their members, this assertion tends to prove the opposite: trade unionists are no longer bureaucrats, distant but defending their interests, but have become bosses against whom one must fight. From then on, the workshop appears to be a place of retreat that must be mobilized. By seeking to directly address the members on the shop floor on the one hand, and to denounce the employer abuses of a the new direction on the other, this letter brings to light the production of new forms of participation in the Corbeil print works. In this respect, the most recalcitrant worker-members perceived the workshops as a possible 'public space' in Habermas's sense: a place where 'public opinion' is produced that is likely, because of the numbers involved, to challenge and influence the decision-making processes of the firm's leaders.

To do this, they relied on a practice from the traditional repertoire of collective action in their professional and union environment: negotiating acceptance of difficult working conditions against monetary compensation that meets specific and long-established amounts. While criticizing the discrepancies between the employer's discourse and practices is also a classic

15 Memorandum by the CEO of Helio Corbeil entitled 'Reorganization of the work schedule during solvent recovery from 21 May to 16 June 2013', 10 April 2013. 
mode of argumentation, here this strategy took a singular form. By pointing out, right from the introduction, that this change "is nothing more than "flexibility" [and that] such a proposal from the previous management would have raised a union outcry from our current CEO', ${ }^{16}$ the letter picked up on the sociological particularity of a board of directors composed of both former and current union representatives. Its authors knew that by suggesting possible betrayals by leaders who not only had not abandoned their trade union membership, but were now claiming their affiliation with the social and solidarity economy, they were drawing on a register that was doubly sensitive for the leadership. In fact, the strategy paid off. Jérôme, a union delegate and member of the board, was immediately willing to concede to their demands. But apart from this almost natural intermediary, a significant share of the new board members were concerned about the criticism coming from the workshops, quite simply because they still worked there.

\section{Workers' control enabled by the management's new sociological composition}

This letter is indicative of how the workers tried to influence the board's decisions, via those board members who shared the workspace with them. Writing had long been a common means of expressing dissatisfaction in the factory, ranging from formal letters addressed to the boss through employee representatives, to tags left on the lockers of managers or colleagues deemed too close to the management. In this case, the letter appeared at a time when some board members were finding pages of the labour code or explicit messages ("CGT=MEDEF""17) stuck on the door of their changing rooms. Nonetheless, what was unprecedented was that the letter's authors displayed it in full view in the workshops. In this sense, the production areas were not only a space for occasional disputes, but the most common source of workers' control over the board of directors.

Board meetings were more often concerned with the company's social climate than with its commercial or financial issues. Board members regularly deliberated together over the criticisms they received from their colleagues, particularly on the admissibility of their remarks. More generally, the board was genuinely concerned about the effects of their decisions. As described in the following excerpt, they often apprehended the reactions of their colleagues when they returned to their workspaces.

The day after that meeting, Antoine calls a 'management information meeting'. He doesn't really have a precise agenda, but he knows he's going to talk about the balance sheet, investments, my presence at the plant, and the plan for a strategic partnership with a book binding company. A whole debate starts up over the announcement of this news. Jérôme stresses the importance of explaining the advantages for the company, but that they should expect more prosaic reactions about parking spaces, lockers or showers. Thierry and Marc, on the other hand, don't want the company's name to be disclosed, because [...] they are convinced that the announcement of the company concerned would spread quickly on the grapevine, knowing that many of Helio's members are in contact with staff from the other company. Antoine seems to think that Thierry and Marc are making a fuss over nothing. In any case, all three Thierry, Marc and Jérôme - insist on the fact that they are always pounced on by the member employees after the meetings. ${ }^{18}$

The fact that the tendering in the print media industry is based on three-year contracts partly explains why the social climate was such a central theme in the board members' discussions. 
During the three-year periods, there was no need to go back over potential clients every month, which freed up time to discuss other topics. Yet the sociological composition of the new board seems to provide more insight into the reasons for the place of social concerns on the management's agenda. Selected by the union delegates at the time of the mobilization, the board members were designated on account of their union involvement in the struggle on the one hand, and for their central roles in the production process on the other. The board also included elected members of the works council and outside directors, as indicated in the following table:

\begin{tabular}{|c|c|c|c|}
\hline \multicolumn{4}{|c|}{ Board of Directors (2012-2015) } \\
\hline Name & Position in the company & $\begin{array}{c}\text { Degree of } \\
\text { union } \\
\text { involvement }\end{array}$ & $\begin{array}{c}\text { Former } \\
\text { position if } \\
\text { different }\end{array}$ \\
\hline Antoine & CEO & $\begin{array}{c}\text { CGT } \\
\text { member }\end{array}$ & $\begin{array}{c}\text { Union } \\
\text { representative }\end{array}$ \\
\hline Benoit & Production Manager & none & \\
\hline Marc & Foreman in the press sector & $\begin{array}{c}\text { CGT } \\
\text { member }\end{array}$ & \\
\hline Jérôme & Automation technician & $\begin{array}{c}\text { Union } \\
\text { representative } \\
\text { and CGT } \\
\text { employee } \\
\text { representative }\end{array}$ & $\begin{array}{c}\text { Employee } \\
\text { representative }\end{array}$ \\
\hline Thierry & Receptionist & $\begin{array}{c}\text { CGT } \\
\text { employee } \\
\text { representative }\end{array}$ & \\
\hline Paul & Sales executive & none & \\
\hline \multicolumn{4}{|c|}{ Invited members (without decision-making powers) } \\
\hline Grégory & Foreman in the press sector & $\begin{array}{c}\text { Works } \\
\text { council } \\
\text { representative } \\
(\mathrm{CGT})\end{array}$ & \\
\hline Bernard & Mechanic & $\begin{array}{l}\text { Secretary of } \\
\text { the works } \\
\text { council } \\
\text { (CGT) }\end{array}$ & \\
\hline Isabelle & Secretary & none & \\
\hline Monique & Accountant & $\begin{array}{c}\text { CGT } \\
\text { member }\end{array}$ & \\
\hline
\end{tabular}




\begin{tabular}{|c|c|c|c|}
\hline Gisèle & none (URSCOP officer ${ }^{19}$ ) & none & \\
\hline $\begin{array}{c}\text { Author } \\
\text { of this } \\
\text { article }\end{array}$ & intern & none & \\
\hline
\end{tabular}

By transforming the composition of its board of directors, the plant changed the company's order of priorities, which, as I have shown elsewhere, also focuses on its productive aspects (Quijoux, 2018). Above all, without realizing it, it set up powerful mechanisms to regulate the decisions taken at the top. By placing employees who still worked in the workshops on the board, it created a continuum of information, contestation and counter-proposal between the spheres of production and decision-making. When they return to their workspaces (workshops, printing presses or offices), the members of the board of directors were regularly questioned or even harassed about the projects and choices discussed at the board meeting. But this continuum was not reduced to 'coercive' bottom-up forms of action. It also took shape in the struggle to have difficult working conditions recognized, as shown in the following extract:

The first hour [of the board meeting] is spent in a review of the general meeting, which quickly turns towards problems of motivation and delegation within the company. Antoine is worried: 'They haven't understood the stakes of the cooperative. Even though they received training, it's if it doesn't concern them.' [...] Benoît: 'Well, we had a very good example with the whole story of the weekend catch-up,' he says, exasperated. 'The guys don't want to make any effort, not even exceptionally. They don't get it that they'd be doing it for themselves. Plus, we're only asking for that one weekend.' Jérôme, who supported the overtime rate at the works council meeting the day before, counters, saying: 'But for the guys, one weekend more is a lot! You notice it. I think it's totally reasonable, and I won't apologize for it. [...] Working on a Sunday is not the same as working on a Tuesday, so it's normal to expect some encouragement. $^{20}$

Here, the presence of Jérôme, the new union delegate, reflects the effects of the sociological transformation of the board of directors. In the face of Antoine's misunderstanding and the moral condemnations of various board members, Jérôme's presence did not only ensure that a dissenting voice was heard. He was also able to clarify or recall more broadly a series of details and socio-professional contexts that the other board members seemed to have forgotten or were taking lightly. If in defending the legitimacy of overtime demands, given the hardship that such a change in the work schedule means for employees, he was fulfilling his role as employee representative, it was also his shared experienced of working with the protesting employees that brought him to hold this position. Of all those present that day at the board meeting, he was the only one to still work shifts ${ }^{21}$ in the production sector and to suffer the social effects of a particular work schedule, and therefore to be able to identify them or remind the other members of the board.

$* * *$

\footnotetext{
${ }^{19}$ URSCOP is the Association of cooperatives.

$20 \quad$ Field notes, April 26, 2013.

21 As a reminder, work at Helio Corbeil is organized in rotating shifts: one week at night - 10pm to 6am; one week in the afternoon $-2 \mathrm{pm}$ to $10 \mathrm{pm}$; one week in the morning - 6am to $2 \mathrm{pm}$; one week off; and finally a weekend (twice 12 hours).
} 
With a few exceptions, trade unionism is going through a more or less intense crisis in most European and North American countries (Kelly, 2004; Andolfatto \& Contrepois, 2016). The many factors that explain this - the massive increase in unemployment, the precariousness of employment and working conditions, bureaucratization, etc. - combined with the recurrent attacks on employee representatives, often lead to the loss of the many skills available to trade unions. In the French case, a number of studies have demonstrated the central importance of employee and union representation mechanisms, particularly during restructurings (Bacon \& Blyton, 2004; Didry \& Jobert, 2010; Collectif du 9 août, 2017). By taking over the management of their factory, the Helio Corbeil trade unionists reached a further stage in the field of possibilities. While one might question their economic ability to manage a company, the aim here is to examine their ability to democratize their company.

In this article, democracy at work does not seem to show divergent results from the analyses published elsewhere. The lack of board elections and of participation in collective deliberations confirms that employees make very uneven use of traditional democratic spaces, and this depends largely on their respective social and symbolic positions. In this regard, the case of Helio Corbeil clearly shows how the group's own social relations and history inhibited a large share of employees from participating in the formal meetings. When faced with experienced union activists bolstered by the successful takeover, the most critical employees did not feel sufficiently legitimate to voice their criticism in public.

However, despite these indications in support of yet another case of 'democratic degeneration' (Michels, 1914), my study qualifies the hypothesis of an oligarchic tendency at Helio Corbeil. While the employees seemed to have no means of directly fighting the new management, they were not condemned to 'keep quiet or be spoken for', contrary to Pierre Bourdieu's famous phrase (1982). The study shows that employees preferred to use their own workspaces to challenge the board of directors and to put forward proposals, which they managed to communicate through various channels (protest letters displayed in the workshops and staff representatives who sat on the board). While the factory layout and the work schedules provide explanatory frameworks for the development of these specific forms of participatory attitudes, it is important to emphasize that these are also the result of trade unionism. The development of a trade union elite did not prevent the other employees from forming a set of critical capacities during their careers in the company. These forms of participation, its discursive registers, and its modalities of action were derived from practices learned in the past that were adjusted to the new employment configuration. In this respect, the trade unionists also played a part in creating the conditions for the participatory continuum between the workshop and the board when forming the new board of directors. By having elected staff representatives and, above all, employees who still worked on the shop floor sit on the board, they enabled their colleagues who were less inclined to express themselves in deliberative spaces to express themselves by more suitable means.

In short, while there is every indication that trade unionism does not seem to be more conducive to broad employee participation than other institutions, some of its characteristics, such as the development of critical thinking or the push for employee representation, appear to constitute potential conduits for participatory practices. 


\section{References}

Andolfatto D. \& Labbé A., (2011), Sociologie des syndicats. Paris : la Découverte

Andolfatto. D., \& Contrepois, S. (2016), Syndicats et dialogue social. Les modèles occidentaux à l'épreuve. Brussels: P.I.E Peter Lang

Azzellini, D. (2018). Labour as a Commons: The Example of Worker-Recuperated Companies. Critical Sociology, 44(4-5), 763-776

Bacon, N., \& Blyton, P. (2004). Trade union responses to workplace restructuring: exploring union orientations and actions. Work, Employment and Society, 18(4), 749-773.

Basterretxea, I., \& Storey, J. (2018), Do Employee-Owned Firms Produce More Positive Employee Behavioural Outcomes? If Not Why Not? A British-Spanish Comparative Analysis. British Journal of Industrial Relations, 56, 292-319

Bourdieu, P. (1982). Ce que parler veut dire. Paris: Fayard.

Broekmeyer, M. J. (1977). Self-Management in Yugoslavia. The Annals of the American Academy of Political and Social Science, 431, 133-40.

Collectif du 9 août (2017), Quand ils ont fermé l'usine. Marseille: Agone.

Darlington R. \& Upchurch M., "A reappraisal of the rank-and-file versus bureaucracy debate", Capital \& Class 36(1) 77-95

Didry C., \& Jobert A. (2010). L'entreprise en restructuration. Rennes : PUR.

Reid, D. (2018). Opening the Gates: The Lip Affair, 1968-1981. London: Verso.

Fernandez Alvarez, M.I. (2016). Productive work as political action: daily practices of struggle and work in a Recovered Factory. The Journal of Latin American and Caribbean Anthropology, 21(2), p.254-275.

Frega, R, Herzog, L, \& Neuhäuser, C. (2019). Workplace democracy-The recent debate. Philosophy Compass, 14:e12574.

Giraud B., Yon K., \& Béroud S. (2018). Sociologie politique du syndicalisme. Paris: Armand Colin.

Gold M. (2004), "Worker Mobilization in the 1970s: Revisiting Work-ins, Co-operatives and Alternative Corporate Plans”, Historical Studies in Industrial Relations n 18, 65-106.

Gourgues G. (2018), Pourquoi ont-ils tué Lip ? Paris : le Seuil.

Greenberg, E. (1981). Industrial Self-Management and Political Attitudes. The American Political Science Review, 75(1), 29-42.

Heery E., \& Kelly J. (1994). Professional, participative and managerial unionism: an interpretation of change in trade unions. Work, Employment \& Society, 8(1), 1-22.

Holloway J., (2010). Crack Capitalism. London: Pluto Press. 
Hyman R (1975) Industrial Relations: A Marxist Introduction. Basingstoke: Macmillan.

Hyman R (1979) "British Trade Unionism in the '70s". Studies in Political Economy 1: 93112

Hyman, R., (1989). The Political Economy of Industrial Relations. Basingstoke: Macmillan.

Hyman R. 'Afterword: What Went Wrong?', in McIlroy et al. (eds), British Trade Unions, Vol. 2, pp. 353-64.

Kenneth, O.A., (1987), The Worker, the Union and the Democratic Workplace. The American Journal of Economics and Sociology, 46(4), 385-397.

Lojkine, J. (1996). le tabou de la gestion. Pantin: le temps des cerises.

Pendleton A. and Robinson A., "employee ownership in Britain today", in the Oxford handbook of mutual, Co-operative and Co-owned business, edited by Jonathan Michie, Joseph R. Blasi and Carlo Borzaga, p.426-441

Michels, R. (1914). Les partis politiques, essai sur les tendances oligarchiques des démocraties. Paris: Flammarion.

Mischi J. (2016) Le bourg et l'atelier, Marseille : Agone.

Ozarow, D., \& Croucher, R. (2014). Workers' Self-management, Recovered Companies and the Sociology of Work. Sociology, 48(5), 989-1006.

Pateman, C. (1970). Participation and Democratic Theory. Great Britain: Cambridge University Press.

Plys, K. (2016). Worker Self-Management in the Third World, 1952-1979. International Journal of Comparative Sociology, 57(1), 1-28.

Quijoux, M. (2011). Néolibéralisme et autogestion, l'expérience argentine. Paris: Editions de l'IHEAL.

Quijoux, M. (2012). Du “zèle” à l'autogestion : retour sur les usines récupérées d'Argentine. Sociologie du travail, 54(2), 178-196.

Quijoux, M. (2018). Adieux au patronat. Vulaines-sur-Seine: le Croquant.

Rebon, J. (2004). Desobedeciendo al desempleo. La experiencia de las Empresas recuperadas. Buenos Aires: PICASO-La Rosa Blindada.

Ruggeri, A., (Ed.). (2010). Informe del tercer relevamiento de empresas recuperadas por los trabajadores: Las empresas recuperadas en la Argentina, 2010. Buenos Aires: Programa Facultad Abierta, Facultad de Filosofía y Letras, Universidad de Buenos Aires.

Taylor, P. A., Grandjean B.D., Tos N.. "Work Satisfaction Under Yugoslav SelfManagement: On Participation, Authority, and Ownership." Social Forces 65, no. 4 (1987): 1020-034.

Thursfield, D. (2012). The social construction of professionalism among organizers and senior organizers in a UK trade union. Work, Employment and Society, 26(1), 128-144. 
Tuckman A. \& Knudsen H., "The Success and Failings of UK Work-Ins and Sit-Ins in the 1970s: Briant Colour Printing and Imperial Typewriters", Historical Studies in Industrial Relations 37 (2016) 113-39

Wright E O. (2010), Envisioning Real Utopias, London: Verso. 